\title{
20
}

\section{CARE AS AN ACT OF INEQUALITY?}

\section{Complex Social Relations Within the Refugee Camp in Brussels' Maximilian Park Throughout 2015}

\author{
Rivka Saltiel
}

\section{Introduction}

The public Maximilian Park in Brussels was the site of a makeshift refugee camp for three months in 2015, when the institutional reception system was insufficient to provide shelter for newly arriving asylum seekers. Local volunteers stepped in, forming a citizens' platform and organizing the space, Camp Maximilian, under the banner of 'Refugees Welcome.' The volunteers consisted of a broad range of individuals, including students, retired persons, registered asylum seekers, undocumented immigrants (sans-papiers), as well as the not-yet-registered asylum seekers who inhabited the camp. Hosting up to 1,000 people, the camp became a space of humanitarian care, but also a space of everyday life, a space of encounter where people came together to play football, make music, hang out, and make friends. This variety of activities attracted various actors with diverse motives to participate in the camp.

The spatial proximity, visibility, and approachability of otherwise systemically marginalized persons led to a specific 'throwntogetherness,' a multiplicity of trajectories simultaneously present (Massey 2005). Emphasizing the complexity of social relations at Maximilian Park, this chapter points to the political and emancipatory potential of care and deconstructs dominant representations of the 'needy' refugee. Therefore, I analyze pivotal moments where equality was performed in communal activities, that not only challenged and temporarily subverted normative accounts of migration and care but also put into question the paternalistic helpdiscourse, which is often observed in voluntary work with refugees (van Dyk and Misbach 2016). I argue that the act of (self-)caring is a political act of equality through which individuals constitute themselves as citizens, as claimants of rights and responsibilities, regardless of their socio-legal status (Isin 2008). Such 'acts of citizenship' (ibid. 2009) introduce a break into routines, understandings, and practices and disrupt perceptions around perceived identities. Furthermore, through assuming the very rights they are seen to be lacking, they bring new actors into being who rewrite the script and create a scene (both as performance and disturbance) (ibid.).

Elaborating on these disruptive acts of equality requires considering the structures, mechanisms, and institutions that produce and maintain exclusion and oppression (Lawson 2007) and 
understanding how normative roles are-how difference is - socially constructed. Therefore, this chapter brings the multiple unequal power relations refugees find themselves entangled in to the fore. It starts with a discussion of the selective logic of the nation-state border and techniques of 'domopolitics' (Walters 2004) that not only systemically produce difference, but consequently also create a (presumed) need for care, constituting the prevailing 'politics of needs interpretation' (Fraser 1987). This is followed by an elaboration of the interrelation of the border regime and the humanitarian care ethics, that both depend on depoliticized and excluded individuals. Consequently, immigrants are reduced to either traumatized dependent victims or criminals and therefore become objects of care or securitization (see Pupavac 2008; Rancière 1998; Rygiel 2012; Walters 2004). After a presentation of the methodological approach, acts of equality at Camp Maximilian are identified, firstly emphasizing the acts of engagement in the making of the refugee camp and the emergence of a new category: the volunteers. Secondly, elaborating on the camp as a space of everyday life, relations were established that disrupted the prevailing hierarchical helper-victim and citizen-non-citizen dialectics and overruled the perceptions of the suffering dependent refugee. These findings are then discussed in relation to the potential and limits of the structures that emerged in Maximilian Park suggesting a right for all to articulate their needs and to engage in caring relations, regardless of their status.

\section{Unequal Relations}

Rather than accepting pre-constituted identities, Doreen Massey (2000: 284) calls for a politics of interrelation, that "concerns itself [...] with challenging, and taking responsibility for, the form of relationships through which those identities are constructed, in which we are individually and collectively positioned and through which society more broadly is constituted." The following demonstrates how difference is systemically constructed, creating and maintaining unequal power relations to further ask how they can be subverted.

\section{Domopolitics and Disruptive Acts of Citizenship}

Acting as a membrane, the selective logic of the nation-state border creates and maintains difference. It classifies individuals, dividing them not only into citizens and non-citizens, but furthermore identifies them (next to desired tourists and expatriates), as 'worthy refugees' and 'illegal immigrants.' The latter two lose their identity and find themselves reduced to having only the identity of 'the other.' They are deprived of their political subjectivity and find themselves "mere object[s] of pity, more commonly hatred" (Rancière 1998: 31f). Represented in discourses that either frame them as patients, worthy of humanitarian protection and care (recognized refugees) or criminals threatening national security (undocumented immigrants), they become objects of professional management (Nyers 2010; Pupavac 2008; Ticktin 2006).

William Walters (2004) introduced the concept of 'domopolitics' to describe the postpolitical policy-tendencies that rationalize security measures in the name of the conception of the sovereign nation-state as a home. Domopolitics not only frame asylum and migration as a concern of securitization but legitimize spatial (and social) segregation. Refugee accommodation is often placed in isolated rural sites, which reflects the perception of refugees as temporary guests. Therefore, contact with - and integration into-the local and urban centers is not desired. In addition, containment serves to better control refugee populations and 
averts the risk of individuals exercising political subjectivity (Papadopoulos and Tsianos 2013: 180). Far away from the political power of decision making (Darling 2013) and distant from the public gaze, they are held in spaces of an existential, social, political, and legal limbo (Isin and Rygiel 2007).

However, these depoliticizing techniques of domopolitics and the normative accounts of forced migration are resisted (Darling 2017: 3). Individuals and groups, despite their formal status, may nonetheless claim rights and responsibilities - rather than solely being treated as objects of exclusion or pity. In such 'acts of citizenship,' the unexpected that intervenes in the given perceptual order is enacted, creating new sites of contestation, belonging, identification, and struggle (Darling 2014; Isin 2008). As opposed to traditional forms of citizenship as a membership associated with rights, privileges, and duties, Engin Isin (2009: 370) conceptualizes citizenship as relational, an "institution in flux embedded in current social and political struggles that constitutes it." Consequently, the performance of political subjectivity is not bound to a "constituted territory or its legal 'subjects': It always exceeds them" (ibid., original emphasis).

\section{Humanitarian Care Ethics and Democracy}

Through domopolitical modes of governance, refugees become objects of care, systemically at the mercy of providers, be it institutional or private ones. Neediness, however, is not a natural condition: It is intertwined in webs of power and processes of inclusion and exclusion. It is through specific mechanisms of 'politics of need interpretation' (Fraser 1987), that some needs are made "politically disabling compared to others" (Tronto 2015: 34).

By choosing 'the poorest' to be eligible for (and assumed to be dependent on) generous care services, humanitarian care ethics reproduce the prevailing politics of need interpretation (Ticktin 2006). 'Refugees Welcome' initiatives often fail to challenge the mechanisms that produce difference and inequality (Saltiel 2020; van Dyk and Misbach 2016) and rather reinstate the hierarchical dialectic of 'generous citizens' as caregivers and 'victimized passive immigrants' as care receivers. It is observed that voluntary work with refugees is often ascribed to a so-called "racism of help" (Byakuleka and Ulu 2016: 18, own translation) that in the act of care (re)establishes relations that refer, at least implicitly, to racist stereotypes of "white supremacy.' Refugees are then encountered with pity rather than respect and left in the position of the grateful supplicant (van Dyk and Misbach 2016: 221).

In her work on undocumented immigrants in France, Miriam Ticktin (2006) outlines how humanitarianism functions as a transnational system of governance tied to capitalism. She analyzes how humanitarian ethics are inscribed in French law through the so-called 'illness clause' and points out how humanitarian practices create categories defining who is excluded (and criminalized) and who is 'on sufferance' (ibid.). Similarly, Jenny Edkins (2003) criticizes human rights discourses for relying on 'innocent victims' conceived as 'bare lifes' (Agamben 1998) that are to be saved and thereby lose their political voice. She expounds on how humanitarianism reinforces the sovereign state, since it is based on the narrative of the human being as a common essence. Consequently humanitarianism, as well as the sovereign state, "produce[s] (and depend[s] on) a particular form of subject: One that is excluded from politics" (Edkins 2003: 256).

Thus, democracy and care - though often perceived as separate because of their seemingly public-private spheres-are deeply intertwined. Care is fundamentally about inequality since 
caregivers are in a position of relative power. Consequently, "a truly equal, [and inclusive] society gives people equal chances to be well cared for, and to engage in caring relationships" (Tronto 2015: 38). At Maximilian Park, caring brought many people together, unsettling the prevailing societal order and the dominant need interpretation.

\section{The Refugee Camp at Maximilian Park}

Maximilian Park is situated in a politically prominent and visible space, right next to the Brussels North station and within the business district. Insights from Maximilian Park were gained retrospectively through eight extensive semi-structured interviews with actors holding various positions and roles inside the camp: people who gained the lead in the citizens' platform, volunteers who stayed a couple of hours, as well as employees from non-governmental organizations (NGOs), and political activists (see Figure 20.1).

In the 'long summer of migration' 2015 (Kasparek and Speer 2015), the dominant sociopolitical climate in Belgium, as in many other European countries, was not in favor of welcoming refugees. Federal government authorities took a clear anti-refugee stance. Attempting to create deterrents, the state secretary for asylum and migration (from the right-wing Flemish Nationalist Party, NVA) spread semi-official letters stating that the Belgian government is incapable of providing housing and assistance for newly arriving asylum seekers (Vandervoordt and De Praetere 2016). According to these announcements, the government limited the asylum registrations to a maximum of 250 per workday and in fact left hundreds of migrants not (yet) included in the asylum procedure, without any institutional support. Pushed into homelessness, they slept and queued in Maximilian Park, right in front of the Foreigners' Office where asylum applications are processed, in order to eventually get registered.

Hundreds of local volunteers subverted the government's approach, coming to demonstrate their hospitality, welcoming and supporting the waiting refugees. The presence of up to 1,000 exiles in the central urban space sparked great (international) media attention that again drew many curious locals to the space of arrival to support and/or to get to know the 'others,' who are usually pushed to the periphery (of society and cities). An informal refugee camp emerged in Maximilian Park (see Figures 20.2, 20.3, 20.4) that lasted for three months. Camping tents were set up for protection from rain, and a nominal degree of privacy. Larger

\begin{tabular}{|l|l|l|}
\hline Name* & Role at Maximilian Park & Date of the Interview \\
\hline Anika & $\begin{array}{l}\text { Researcher of solidarity practices, participant observer and volunteer } \\
\text { with CollectActif in the camp's kitchen }\end{array}$ & $10-1-2017$ \\
\hline Chiara & Activist for regularization of sans-papiers, CollectActif & $14-3-2017$ \\
\hline Lisa & Employee humanitarian NGO, providing legal advice for refugees & $14-3-2017$ \\
\hline Lukas & Anarchist activist, student & $19-6-2016$ \\
\hline Mourad & Volunteer Platform, employee tech-company & $17-7-2017$ \\
\hline Rebecca & Coordinator for a medical humanitarian NGO, nurse & $18-7-2017$ \\
\hline Sahar & Volunteer Platform, student & $24-4-2017$ \\
\hline Sofia & Core-group and spokesperson of Platform, student & $20-10-2016$ \\
\hline
\end{tabular}

FIGURE 20.1 Interviewees. Source: Rivka Saltiel, 2020. 


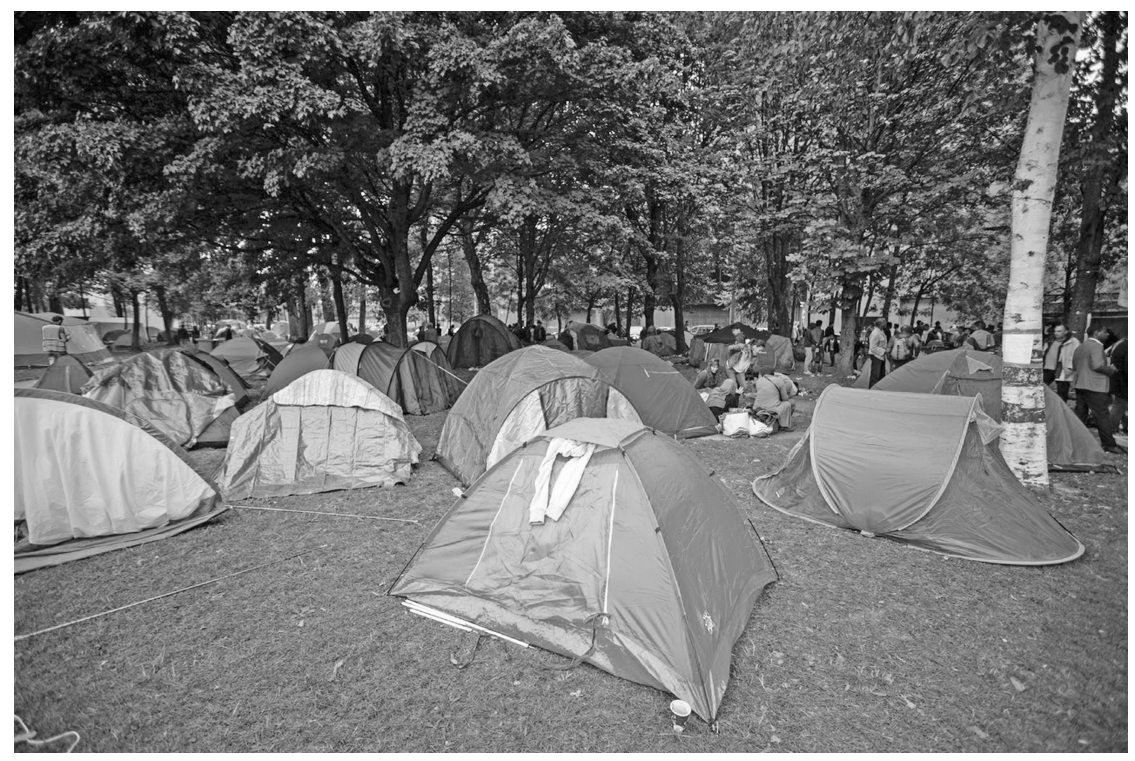

FIGURE 20.2 Maximilian Park, first days. Source: David Crunelle, 2015.

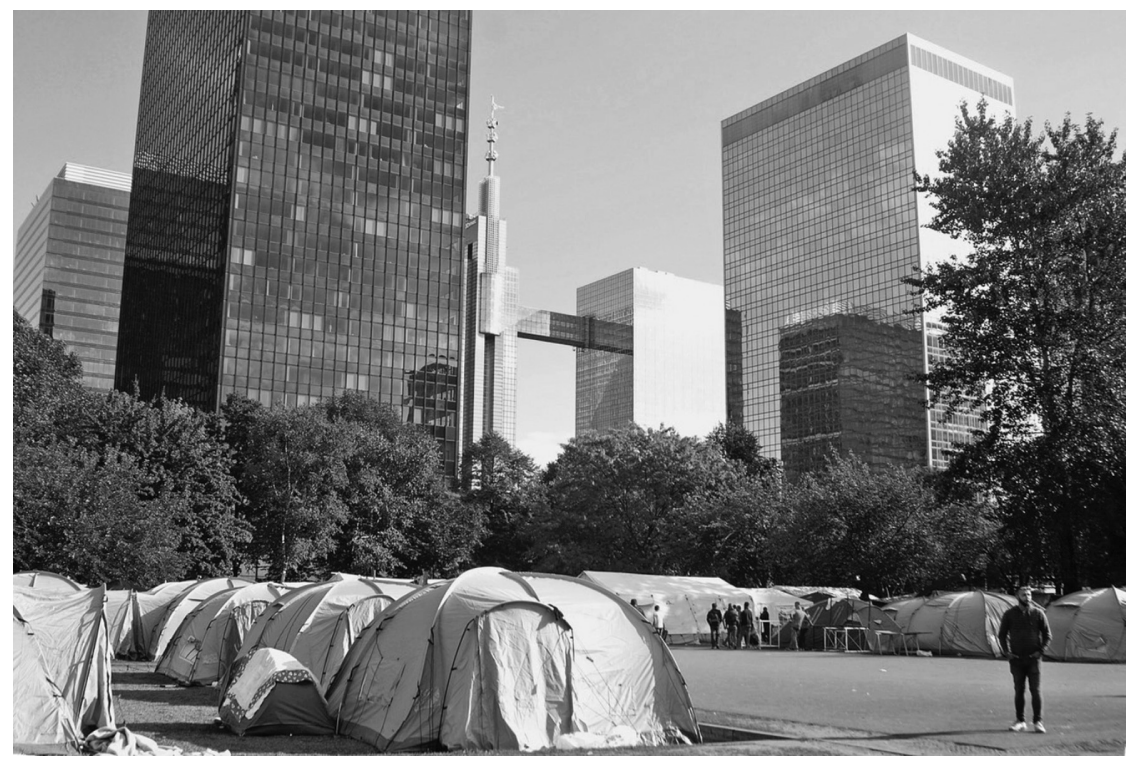

FIGURE 20.3 Maximilian Park, after some weeks. Source: Coralie Vankerkhoven, 2015.

tents provided space for various services such as acute medical care, psychological support, legal advice, storage space for contributions of clothing and sleeping bags, allocation of tents, language courses, a school for children, a cinema, etc. Containers were set up with hygienic facilities. A legal organization, Plateforme Citoyenne de Soutien aux Réfugiés [Citizens' Platform in Support of Refugees; further referred to as Platform] was formed on site that took the lead 


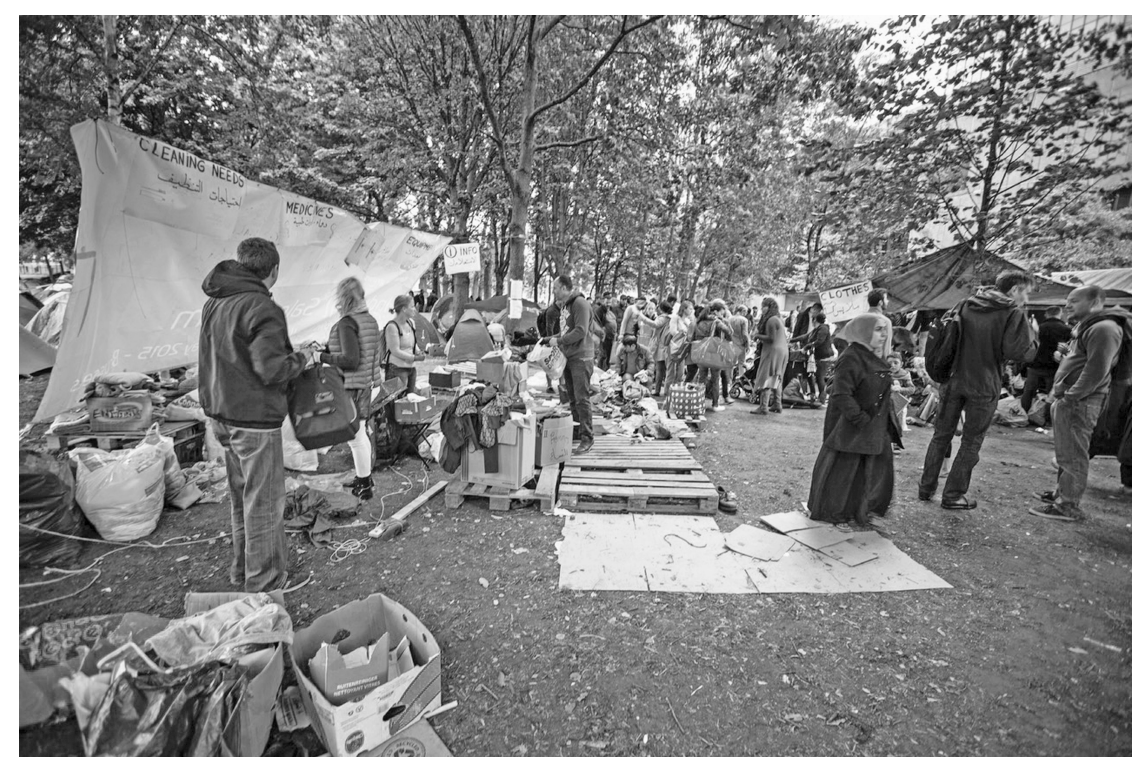

FIGURE 20.4 Volunteers. Source: David Crunelle, 2015.

in organizing the camp. The Platform took on the decision-making power in the camp, represented the camp in front of the media, and led negotiations with city and state authorities. Alongside the Platform, various associations, collectives, and (N)GOs operated on site. The CollectActif, a collective of sans-papiers, for example, built a kitchen in (and as) the center of the camp, providing 1,000 meals per day (see De Praetere and Oosterlynck 2017).

The decision-making members of the Platform explained their commitment as "solving a crisis," filling a gap in the governmental care provision (Sofia, personal communication, October 2016). They demanded federal authorities to guarantee shelter for all asylum seekers and reached an agreement that once their claim was met, the Platform, together with most of the NGOs, would vacate the park.

\section{The Volunteers and the Emergence of a New We}

At Maximilian Park, refugees were no longer merely objects of professional management at a distance from society (Pupavac 2008: 280). Rather, the group of voluntary care providers was comprised of diverse individuals of different genders, ages, origins, and (legal and class) statuses, such as university professors and long-time unemployed persons, activists involved in immigrant protests or individuals who had never had contact with an asylum seeker before. The inhabitants of the camp engaged in the making of the camp along with numerous registered asylum seekers living at asylum centers and returning to the park as volunteers and/ or to hang out.

Apparently, there was a sudden 'hype' around Maximilian Park and involvement in refugee support: "Suddenly everybody wanted to help out because it was such a media thing. Everybody knew about it, everybody talked about it, everybody wanted to help out and suddenly everything was possible" (Rebecca, personal communication, July 2017). Chiara 
(personal communication, March 2017) remembers that sometimes there were even too many volunteers: "Everybody wanted to do something! So, there was a lot (!) of volunteers and we don't need 25 volunteers in the small kitchen."

The camp created new actors of care and volunteers were re-contextualized as a new social category. Its members were identifiable by wearing shiny safety vests. People could present themselves anew and were "valued for what they wanted to do" (Lisa, personal communication, March 2017). Regardless of one's socio-economic and/or legal status, there was "a mutual understanding of each other as colleagues” (Sahar, personal communication, April 2017).

Refuting the representation of undocumented migrants as a threat to society was an incentive for CollectActif to engage in the park. As explained by Chiara (personal communication, March 2017): "To show that undocumented migrants are not [in Brussels] just to make crazy stuff and [to show that] they're not terrorists, [...] not criminals, but [that] we really do something better for the society." Indeed, they proved to be

equally capable in organizing solidarity as Doctors of the World, some people even thought they were an official Brussels Government Agency taking care of the food and the park. [...] People didn't know about their status. So, they just made an evaluation of the acts they did.

(Anika, personal communication, January 2017)

For many volunteers, the camp became the center of their lives for three months. They integrated themselves into this new social network and found their place within this microcosm. Many came to the park on a regular basis, some daily, others lived in the camp for a period of time. While volunteers often initially planned to stay for a few hours, they ended up staying longer and returning frequently. However, assuming responsibility also led to overburdened and exhausted volunteers in many cases, who then needed care themselves. After some weeks, leaflets were distributed advising volunteers to take breaks, restrict their hours in the park, get enough sleep, and consult support if needed. In addition, a tent for psychological care for volunteers was set up. "It was often not clear who was helping whom. [...] It wasn't like; this is the receiving and this is the providing end of the solidarity" (ibid.).

\section{More Than Care: The Camp as a Space of Everyday Life}

The park, with its children's playground and football field, kept its function as a public space. A wide range of everyday activities were practiced there that went beyond the activities of emergency response, logistics, and help. Children played football, while a French language course was held in a different corner of the park. Elsewhere in the park, a group of people gathered with different instruments and played music, sang, and danced. Others hung out next to the kitchen, while a screen was set up for movies at the Cinémaximilian. "Every night people were dancing, playing music, making barbeque" (Mourad, personal communication, July 2017). Sahar, a student who had just moved to Brussels herself, recalls that she enjoyed spending time in the park. She went there regularly, sometimes for volunteering, other times just to hang out and chat with people. Sahar made many friends at the camp with whom she is still in contact. The camp was a social space with the potential for people to engage in casual interaction, create networks, and establish friendships that could facilitate their individual process of arrival in Belgium. Mourad (ibid.) stresses this specific aspect, stating that "they were lucky 
in the end. [...] And honestly when we look at it today, we notice they are way further with the integration than the others. When they start to look for a job they know more people."

However, the openness of the camp and its multiplicity of activities and actors were also perceived as controversial. Lisa, working for a humanitarian NGO, for example, disapproved of the social gatherings. The fact that some people enjoyed being in the park seemed to counteract her endeavors to push the government to provide formal shelter for all refugees so that the park's new function as a camp would no longer be necessary.

\section{The Re-Production of Classifications}

The vast public attention the camp received made the refugees' arrival visible and politicized it. Thereby it sparked not only support but also hostility. Paradoxically, though the lack of care and the construction of the camp was a consequence of government decisions, elected officials reacted to the situation by stating the camp was "too cozy" (Francken 2015, own translation $)^{1}$ or describing the camp as a "place that often looks like camping, a funfair, yes, even a music festival" (RTL Info 2015, own translation). ${ }^{2}$ Apparently, there is a discrepancy between a certain degree of fun, comfort, and self-determination on the one hand, and domopolitical technocratic governing that prioritizes securitization and isolation on the other.

Furthermore, as interviewed persons reported, government authorities provocatively labelled all volunteers as of the 'extreme left.' In addition, they pointed out the different origins of migrants making allegations that the camp is full of sans-papiers and sending out 'warnings' that many of the campers were not actually eligible for refugee status and were therefore considered illegal immigrants. Thereby, they did not only put into question who cares for whom but re-introduced classifications within the camp.

The camp became more and more exclusive, both in its organizational structure and in the selection of certain individuals eligible to receive care. The Platform, whose core team consisted of a few 'white' Belgian students, professionalized and its structures stabilized. Although Sofia (personal communication, October 2016) stated that "there is no division in misery" and advocated for equal treatment of everyone inside the camp, the provision of care services was eventually limited to asylum seekers only (while care still could be provided by anyone). Other migrants, homeless people, and others seeking medical care, hygienic infrastructure, a tent, clothing, or a sleeping bag were excluded from the camp's care regime and referred to pre-existing organizations. Representations of the 'deserving refugee' and the criminalized undocumented migrant were reinforced, re-inscribing and excluding already marginalized identity positions.

Interviewees reported that some volunteers and donors exclusively wanted to help Syrians. Syrians, the most likely to receive asylum in Belgium, were regarded as the poorest and thus as the most deserving. That again reinforced conflicts along ethnic lines and led to a demarcation of categories bound to nation-states. Sahar (personal communication, April 2017), volunteering with the Platform to distribute tents, recalls her dilemma:

When they [sans-papiers] would come to the housing unit asking for tents, I transformed into this person: "No, you're not a refugee arriving just now, so I can't give you a tent." And I had some tension with some of them. So, one guy shouted with me: "I need a tent more than [...] other people." [He] was speaking French and Moroccan Arabic. He was very angry with me. And then I was really sad. Because also my reaction to him was: 
Don't you think that it's unfair that you come and ask for a tent when some people have made the journey for days, walking, and need a place to sleep?

Many sans-papiers were present in the camp, both as volunteers and as activists, raising awareness of their political struggle to receive papers. However, they were excluded from receiving the services and moreover from the decision-making processes in the camp. This eventually led to severe conflicts between the Platform and some sans-papiers (see De Praetere and Oosterlynck 2017; Saltiel 2020).

\section{Disrupting Hierarchical Relations: Care as Act of (In)Equality}

The camp, through its centrality, visibility, and supposed openness, evoked a specific 'throwntogetherness' (Massey 2005). The relationships that resulted from this space of encounter were complex. There was not one camp for one purpose, but a simultaneous multiplicity of camps and purposes: the camp as a space of emergency-care, of political struggle, a shelter, a place to 'help,' a place to jam, to establish networks. It was a space where power relations were negotiated and temporarily subverted. Undocumented migrants, long-time unemployed persons, asylum seekers, those who are marginalized in their day-to-day lives, all became part of the Maximilian Park community. In this setting their 'usual' and marginalizing identities became irrelevant. They were identified by the roles they took on in the park, for example, that of a musician, a volunteer, or an athlete. A new 'we' emerged alongside the ongoing activities and a deep sense of community and belonging arose around Maximilian Park (May 2010).

A different mode of refugee reception was enacted at Maximilian Park. In communal activities (be it volunteering, or other every-day-activities in the public space), hierarchical societal roles were redistributed. Furthermore, the representations of refugees as a threat to securitythat they are to be contained on the margins of society — was challenged. Consequently, the presence of immigrants in urban space was a claim to participate in the social life of the city. Friendships were established, and networks were created that facilitated the arrival of the asylum seekers and their settling in the city. Domopolitics was disrupted and, as opposed to being isolated, only in contact with fellow asylum seekers and 'professionals' in an immigration center, the refugee camp at Maximilian Park allowed for many different people to engage with each other and in the camp's activities.

The variety of volunteers not only challenged dominant accounts of forced migration, but also revealed how neediness is systemically constructed. Furthermore, it depicts how regimes of care and migration are entangled, creating difference in order to sustain processes of depoliticization and exclusion of certain individuals. At Maximilian Park, volunteers collectively staged a presumption of equality and demonstrated the ability to care for the community. Refugees and undocumented immigrants acted as citizens. Regardless of their legal and/or citizenship status, they affirmed the power to self-manage and organize their affairs (Swyngedouw 2014: 31). These acts put the dominant politics of need interpretation into question in a two-fold manner. Firstly, the vast support of locals made the very need for care and shelter visible, subverting the government's approach and the lack of care provision. Secondly, the temporary subversion or dissolution of the normative categories of caregivers and care receivers in the camp disrupted a humanitarian care ethics that tends to reproduce discourses of domopolitics that reinforce unequal power relations between presumed benefactors and 'poor suffering refugees.' However, due to different internal and external 
processes and conflicts that arose over time, the moments of de-classification were hamstrung. The assertion of a humanitarian logic within the camp re-enacted the selective divisions of domopolitics and re-inserted categories by choosing exceptional individuals worthy of care while excluding the rest (Darling 2013; Ticktin 2006).

Paradoxically, though any act of care is unequal (Tronto 2015: 14), caring not only produces but may also subvert hierarchical relationships (ibid.: 35). When perceived care receivers perform the capacity to care (for her-/himself and for others), normative roles are disrupted, consequently putting into question prevailing post-political mechanisms to create difference and legitimize exclusion. Democracy and care are deeply interwoven and caring allows depoliticized subjects to reclaim power and responsibility.

However, caution is required not to downplay migrants' experiences and suffering along the journey or to romanticize the precarious conditions of Maximilian Park. The very lack of governmental care provision produced urgent existential and material needs for shelter, food, and medical care. Rights were denied, and responsibilities were outsourced to nonprofessional and non-paid individuals causing immense psychological stress for many who took on these tasks. This chapter does not suggest that a withdrawal of responsibilities by government authorities is beneficial to a more equal society. It rather suggests that caring is the responsibility of the society as a whole. Therefore, a society needs to organize itself around care, consequently taking responsibility for and challenging the relationships through which identities are constructed (Massey 2000).

The experiences in the camp reveal that neediness is not bound to a specific socio-legal status, but that we are all bodies that care and are cared for (Butler 2004). Thus, learning from Maximilian Park does not only suggest a right for all to care (both being cared for and engaging in caring relationships), but a right to articulate, to act, and to be treated according to true individual needs (Tronto 2015). By this means, regimes of unequal power relations are disrupted, allowing for re-subjectivation and autonomy of refugee individuals and potentially a solidarity based on an understanding of equality and interrelation.

\section{Notes}

1 Theo Francken (2015) was the Belgian State Secretary for Asylum and Migration. He posted on his Twitter account: "Ik bied basic-preopvang aan. 14 gaan erop in. Ze willen gewoon nt. Tentenkampje te knus blijkbaar. Kritiek stopt hier. Excuses welkom. Dank." In stating that he opened basic provision, he refers to rudimentary shelters that opened after the establishment of the camp. However, these shelters—solely open overnight—were in such poor condition that refugees preferred staying in the camp.

2 The second quote derives from a newspaper interview with Alexander De Croo, who was Deputy Prime Minister in 2015.

\section{References}

Agamben, G. (1998) Homo Sacer: Sovereign Power and Bare Life. Stanford: Stanford University Press.

Butler, J. (2004) Precarious Life: The Powers of Mourning and Violence. London: Verso.

Byakuleka, B.B. and Ulu, T. (2016) Der Rassismus des Helfens: Warum so viele Willkommensinitiativen nicht politisch über die Flüchtlingsfrage sprechen wollen. Analyse und Kritik 613: 18-19.

Darling, J. (2013) Asylum and the Post-Political: Domopolitics, Depoliticisation and Acts of Citizenship. Antipode 46(1): 72-91.

Darling, J. (2014) From Hospitality to Presence. Peace Review 26(2): 162-169. 
Darling, J. (2017) Forced Migration and the City: Irregularity, Informality, and the Politics of Presence. Progress in Human Geography 41(2): 178-198.

De Praetere, A. and Oosterlynck, S. (2017) 'I Finally Found My Place': A Political Ethnography of the Maximiliaan Refugee Camp in Brussels. Citizenship Studies 21(6): 693-709.

Edkins, J. (2003) Humanitarianism, Humanity, Human. Journal of Human Rights 2(2): 253-258.

Francken,T. [@FranckenTheo] (2015, September 8) Ik bied basic-preopvang aan.14 gaan erop in. Ze willen gewoon nt. Tentenkampje te knus blijkbaar. Kritiek stopt hier [Tweet]. Available at https://twitter.com/ FranckenTheo/status/641138165416361984?ref_src $=$ twsrc\%5Etfw\%7Ctwcamp\%5Etweetembed \%7Ctwterm\%5E641138165416361984\&ref_url=https\%3A\%2F\%2Fwww.lalibre.be\%2Fbelgique $\% 2$ Ftheo-francken-qualifie-faycal-cheffou-de-djihadiste-extremiste-56f8db6835702a22d5d0e0e7 [Accessed 25 May 2020].

Fraser, N. (1987) Women, Welfare and the Politics of Need Interpretation. Hypatia 2(1): 103-121.

Isin, E.F. (2008) Theorizing Acts of Citizenship. In E.F. Isin and G.M. Nielsen (eds.) Acts of Citizenship. New York: Palgrave Macmillan, pp. 15-43.

Isin, E.F. (2009) Citizenship in Flux:The Figure of the Activist Citizen. Subjectivity 29(1): 367-388.

Isin, E.F. and Rygiel, K. (2007) Abject Spaces: Frontiers, Zones, Camps. In E. Dauphinee and C. Masters (eds.) The Logics of Biopower and the War on Terror. New York: Palgrave Macmillan, pp. 181-203.

Kasparek, B. and Speer, M. (2015) Of Hope: Ungarn und der lange Sommer der Migration. Border Monitoring [Online]. Available at https://bordermonitoring.eu/ungarn/2015/09/of-hope [Accessed 10 February 2020].

Lawson, V. (2007) Presidential Address: Geographies of Care and Responsibility. Annals of the Association of American Geographers 97(1): 1-11.

Massey, D. (2000) Entanglements of Power: Reflections. In J. Sharp, P. Routledge, C. Philo and R. Paddison (eds.) Entanglements of Power: Geographies of Domination/Resistance. New York: Routledge, pp. 279-286.

Massey, D. (2005) For Space. London: Sage Publications.

May, T. (2010) Contemporary Political Movements and the Thought of Jacques Rancière: Equality in Action. Edinburgh: Edinburgh University Press.

Nyers, P. (2010) No One Is Illegal Between City and Nation. Studies in Social Justice 4(2): 127-143.

Papadopoulos, D. and Tsianos, V.S. (2013) After Citizenship: Autonomy of Migration, Organisational Ontology and Mobile Commons. Citizenship Studies 17(2): 178-196.

Pupavac, V. (2008) Refugee Advocacy, Traumatic Representations and Political Disenchantment. Government and Opposition 43(2): 270-292.

Rancière, J. (1998) The Cause of the Other. Parallax 4(2): 25-33.

RTL Info (2015, 12 September) Alexander De Croo souhaite "évacuer le parc Maximilien": "C'est à la fois un camping, un marché, presque un festival de musique" [Online]. Available at www.rtl.be/info/belgique/ politique/alexander-de-croo-souhaite-evacuer-le-par-maximilien-c-est-a-la-fois-un-camping-un -marche-presque-un-festival-de-musique--753590.aspx [Accessed 25 May 2020].

Rygiel, K. (2012) Politicizing Camps: Forging Transgressive Citizenships in and Through Transit. Citizenship Studies 16(5-6): 807-825.

Saltiel, R. (2020) Arrival Infrastructures Between Political and Humanitarian Support. Or: The Refugee Welcome Movement Revisited. Urban Planning 5(3): 67-77.

Swyngedouw, E. (2014) Where Is the Political? Insurgent Mobilisations and the Incipient 'Return of the Political'. Space and Polity 18(2): 122-136.

Ticktin, M. (2006) Where Ethics and Politics Meet: The Violence of Humanitarianism in France. American Ethnologist 33(1): 33-49.

Tronto, J.C. (2015) Who Cares? How to Reshape a Democratic Politics. Ithaca: Cornell University Press.

van Dyk, S. and Misbach, E. (2016) Zur politischen Ökonomie des Helfens: Flüchtlingspolitik und Engagement im flexiblen Kapitalismus. Prokla 46(2): 205-227.

Vandervoordt, R. and De Praetere, A. (2016) Subversive Humanitarianism: Understanding the Civil Refugee Support in Europe. Unpublished manuscript.

Walters, W. (2004) Secure Borders, Safe Haven, Domopolitics. Citizenship Studies 8(3): 237-260. 